\title{
Protective Effect of Gum Arabic/Insulin Against Histological Changes in Testes of Diabetic Rats
}

\author{
Efecto Protector de la Goma Arábiga/Insulina Contra los \\ Cambios Histológicos en los Testículos de Ratas Diabéticas
}

\author{
Amin Abdullah Al-Doaiss ${ }^{1,2}$ \& Mohammed Ali Al-Shehri ${ }^{1}$
}

\begin{abstract}
AL-DOAISS, A. A. \& AL-SHEHRI, M. A. Protective effect of gum Arabic/insulin against histological changes in testes of diabetic rats. Int. J. Morphol., 38(2):340-347, 2020.

SUMMARY: Diabetes mellitus is a serious disease with a high incidence of occurrence in our community. Gum Arabic (GA) is a branched-chain polysaccharide which has strong antioxidant properties, and has been used to reduce the experimental toxicity. Yet, the effects of GA on testicular tissue in type I diabetic rats have not been enough investigated. This study was designed to investigate histological changes in testes of male Wistar rats and investigate the protective potential of GA against diabetes- induced testicular toxicity in rats. Fifty adult male Wistar rats were assigned into five groups ( $\mathrm{n}=10 \mathrm{of}$ each): Group 1 (non-diabetic rats) served as control, Group 2 served as diabetic group injected with Alloxan, Group 3 diabetic group plus insulin, Group 4 diabetic group given $15 \%$ GA in drinking water and Group 5 diabetic group plus insulin and GA for 4 weeks. Compared to control group, histopathological examinations of testicular tissue from the diabetic rats group, showed degeneration, necrosis and atrophy of seminiferous with presence of giant cells. Necrosis and hemorrhage in the renal tissue. On the other hand, treatment with GA ameliorated all the previous histological changes. Overall, oral administration of GA alone or with insulin daily for 4 weeks successfully ameliorated the testicular histological changes. These data demonstrated that GA significantly improved diabetes complication in rat testis. This study suggested that GA might have a protective effect against oxidative stress-induced impaired testicular functions in diabetic rats. The possible mechanisms of this action might be ascribed to their antioxidant and anti-inflammatory properties.
\end{abstract}

KEY WORDS: Diabetes mellitus; Testes; Gum Arabic; Histology; Rat.

\section{INTRODUCTION}

Gum Arabic (also known as gum Acacia, GA) is defined as an edible, water-soluble dietary fibrous heteropolysaccharide, made from the dried gummy exudate obtained and cultivated as a cash crop in agroforestry systems from the stems and branches of Acacia senegal or Acacia seyal trees (Said et al. 2019). GA is rich in $\mathrm{Ca}_{2}{ }^{+}, \mathrm{Mg}_{2}{ }^{+}$and $\mathrm{K}^{+}$, widely used in the pharmaceutical, cosmetic and food industries as an emulsifier and stabilizer (Ali et al., 2013; Nasir, 2013). Experimentally, Arabic gum has been used in Middle East and North Africa countries in the traditional treatment of variety of diseases, such as renal failure, hepatic, cardiac, anemia and diabetes mellitus, also used as an oral hygienic substance, antidiarrheal and anti-inflammatory for intestinal mucosa and inflamed skin, it improves the patients' digestive systems and improves appetite, and for kidney disease patients (Zeid \& FarajAllah, 2018; Nasir; Elshama, 2018; Said et al.). In mice and rats, GA has been reported to act as protecting agent against hepatic and renal toxicities (Nemmar et al., 2019). The protective effects of AG are likely to be related to its anti-oxidant and anti-inflammatory and cytoprotective properties (Helal et al., 2011; Hammad et al., 2019). It is a widely known safe dietary fiber with varied applications within the food, pharmaceutical and cosmetic industries. In the colon GA is degraded by microorganisms to short chain fatty acids (Nasir).

Diabetes mellitus (DM) is a common progressive serious metabolic disease. It is considered one of the most common chronic diseases worldwide (Hashem, 2018). It is caused by inherited and/or acquired deficiency in production of insulin by the pancreas, or by the ineffectiveness of the insulin produced. According to World Health Organization (WHO) reports, by the year 2025 more 346 million individuals will have DM, this number will increase to 439

\footnotetext{
${ }^{1}$ Department of Biology, College of Science, King Khalid University, Abha, Saudi Arabia.

${ }^{2}$ Anatomy and Histology Department, Faculty of Medicine, Sana'a University, Sana'a, Republic of Yemen.
} 
million, almost $10 \%$ of adults, by 2030 (Dag et al., 2014; Almalki et al., 2019). Diabetes mellitus is characterized by hyperglycemia and endocrine disorder leading to male infertility by affecting sperm quality through altered steroidogenesis (biosynthesis of steroid hormones) (Popoola et al., 2017). Both major types of DM affect b-cells mass and insulin secretion (Meier \& Bonadonna, 2013).

Therapeutically, treatment by the natural products may be more effective and safe as alternative treatment for DM compared with chemical hypoglycemic agents, and low cost for many diseases and disorders. (Almalki et al.). According to the US Food and Drug Administration (FDA), GA is one of the safest dietary fibers (Nasir). Recently, there has been a growing interest in using natural phytochemical compounds as treatment alternatives in several conditions including diabetes, so the recent trend is encouragement for using natural products or medicinal plants as alternative therapies attributed to the increase of medication cost and synthetic medicinal side effects. Traditional therapies established from natural products showed an impact role in the control of DM (Cheng et al., 2013; Hammad et al.). Experimental studies yielded evidence for an antioxidant and anti-inflammatory properties of GA as well as protective effects in hepatic-, renal- and cardiac toxicity, decrease blood pressure and cholesterol concentrations and antimicrobial activity (Nasir; Hammad et al.).

However, the protective effect of gum Arabic with insulin on testes health of diabetic rats is poorly understood. The aim of this study was to evaluate the possible protective effect of GA/insulin on testicular tissue of diabetic rats.

\section{MATERIAL AND METHOD}

Chemicals: Alloxan monohydrate and Gum Arabic (GA) powder were obtained from Sigma- Aldrich Co, Germany.
Experimental Animals: A total of 50 male Wistar albino rats weighing (200-250 g 10 weeks old) were utilized in this study. The animals were supplied from the animal house of Faculty of Science (King Khalid University, Abha, KSA). The animals were kept in cages under proper environmental conditions of temperature, humidity, and light and had free access to food and water. The animals were acclimatized to the laboratory conditions for 7 days prior to the experiment. The animal handling procedures were conducted according to the ethical norms approved by the Ethical Committee of Faculty of Science, King Khalid University.

Induction of type 1 diabetes: To induce diabetes mellitus, after 12-hour overnight fasting, the rats received an intraperitoneal injection of freshly prepared alloxan monohydrate $(150 \mathrm{mg} / \mathrm{kg}$ b.w) in normal saline. Alloxan induces diabetes within 3 days by destroying the beta cells. After $72 \mathrm{~h}$, animals with fasting blood glucose levels of $>200 \mathrm{mg} / \mathrm{dl}$ were considered diabetic and used for further experiments (Pashapoor et al., 2019).

Experimental design: Rats were divided into six groups of $n=10$ each, the different treatment groups their dosing and route of administration is given in Table I.

All the groups were treated for 30 consecutive days, At the end of this period, animals were sacrificed, testes were removed for the determination of histopathological examinations.

Histological examination: Testes were carefully dissected out following abdominal incision and fixed in neutral buffered formalin $(10 \%)$, then dehydrated, with grades of ethanol (70, 80, 90, 95 and $100 \%)$. Dehydration was then followed by clearing the samples in 2 changes of xylene, impregnated with 2 changes of molten paraffin wax using an automatic tissue processor (Sakura, Japan), then embedded and blocked out using an embedding station

Table I. Experimental groups used in this study.

\begin{tabular}{|c|c|c|}
\hline Group No. & Group Name & Dosage \\
\hline Group 1 & Control $=$ Non-diabetic rats & Received $2 \mathrm{ml}$ normal saline orally \\
\hline Group 2 & Diabetic rats & $\begin{array}{l}\text { Rats received a single dose of alloxan }(150 \mathrm{mg} / \mathrm{kg} \text {, intraperitoneal } \\
\text { (i.p.) injection. }\end{array}$ \\
\hline Group 3 & Diabetes + Gum Arabic & $\begin{array}{l}\text { single dose of alloxan }(150 \mathrm{mg} / \mathrm{kg} \text {, intraperitoneal (i.p.) injection. } \\
\text { diabetic rats treated with }(15 \mathrm{mg} / \mathrm{kg} / \mathrm{B} \text {. W./day) Arabic gum gavage, } \\
\text { GA was dissolved in sterile water just before use }\end{array}$ \\
\hline Group 4 & Diabetes + insulin & $\begin{array}{l}\text { Diabetic rats treated with insulin (4 IU/day). Insulin was } \\
\text { subcutaneously administered each day }\end{array}$ \\
\hline Group 5 & Diabetes + Gum Arabic+ insulin & $\begin{array}{l}\text { Diabetic rats received insulin ( } 4 \mathrm{IU} / \text { day) plus gum Arabic }(15 \mathrm{mg} / \mathrm{kg} / \\
\text { B.W./day) gavage. }\end{array}$ \\
\hline Group 6 & Gum Arabic & $\begin{array}{l}\text { Rats received ( } 15 \mathrm{mg} / \mathrm{kg} / \mathrm{B} . \mathrm{W} . / \mathrm{day}) \mathrm{GA} \text { gavage using intragastric } \\
\text { tube once daily for } 30 \text { days. GA was dissolved in sterile water just } \\
\text { before use. }\end{array}$ \\
\hline
\end{tabular}


(Sakura, Japan). The $5 \mu \mathrm{m}$ thicknesses sections were cut using a microtome (ModelRM2245, Leica Biosystems, Wetzlar, Germany). Paraffin sections were stained by Hematoxylin \& Eosin using an autostainer (Model 5020, Leica Biosystems, Wetzlar, Germany) according to the method described by (Al-Doaiss et al., 2019; Al-Doaiss \& Jarrar, 2019), and examined for alterations in the brain tissues of each rat under study by using optical microscope (Olympus Microscope BX51 with Digital Camera, Japan).

For a semi-quantitative comparison of the structural changes, the abnormalities in the tissue sections were graded from - (normal structure) to +++ (severe pathological changes) (Table II).

Table II. Semi-quantitative analysis of histopathological studies on rat in different groups.

\begin{tabular}{|c|c|c|c|c|c|c|}
\hline & Control & $\mathbf{D}$ & D+GA & D + insulin & D+insulin+GA & GA \\
\hline \multicolumn{7}{|l|}{ Criteria of testes } \\
\hline Normal spermatogenesis & - & +++ & - & - & - & - \\
\hline Abnormal spermatogenesis & - & +++ & + & + & + & + \\
\hline Absence spermatogenesis & - & +++ & - & - & - & - \\
\hline spermatogenesis with Heterogeneity & - & +++ & - & + & - & - \\
\hline Edema in Interstitial tissue & - & +++ & + & + & + & + \\
\hline Separation of cell from basal region & - & +++ & - & + & - & - \\
\hline $\begin{array}{l}\text { Degenerative changes in seminiferous } \\
\text { tubules }\end{array}$ & - & +++ & - & + & + & - \\
\hline
\end{tabular}

$\mathrm{D}=$ Diabetes, $\mathrm{GA}=$ gum Arabic. $-=$ negative, $+=$ mild, $++=$ moderate, and +++ = severe.

\section{RESULTS AND DISCUSSION}

Histopathological observations of the testes of normal control rats revealed normal architecture of the seminiferous tubule. The seminiferous tubules were hexagonal or rounded and are separated by a thin intertubular interstitial connective tissue. The germinal epithelia are formed of normal spermatogenic layers represented by spermatogonia, primary and secondary spermatocytes, spermatids and sperms (Figs. 1A-D). Diabetic rats showed testicular atrophy, and degenerative changes in spermatogenic cells lining the seminiferous tubules, associated with incomplete spermatogenesis. The interstitial tissue becomes wider and vacuolation, the seminiferous tubules were shrunken and greatly depleted of germ cells (Figs. 2A-D). Improvement in the histopathological picture was noticed in examined sections from diabetic rats + GA as the examined sections revealed apparent normal seminiferous tubules and interstitial tissues occupied by the interstitial cells (Leydig cells). Most of their seminiferous tubules were close together with regular outlines and narrow interstitium (Figs. 3A-B). G4 (Diabetes + Insulin) and G5 ( Diabetes + Insulin + Arabic gum) showing normal structure of seminiferous tubules (Figs. 4A-B) and (Figs. 5A-B), respectively.

Results of present study suggested that GA shows a protective effect on alloxan-induced testicular impairment. Hyperglycemia toxicity could induce testicular injury, oxidative stress and apoptosis in diabetes by increasing ROS production and inhibiting of antioxidant defense system
(Dkhil et al., 2016). However, treatment of testicular injury remains challenging, Arabic gum has hypoglycemic effect, it could reduce pathological effects, oxidative stress and apoptosis from diabetic pancreas, GA may serve as an alternative treatment for testicular and pancreatic injury in diabetes (El-Nagar, 2017). Arabic gum alone or with insulin significantly attenuated most of the diabetic-induced histological changes. This protective effect was accompanied by a tendency to improve somniferous tubular structure (Hammad et al.). In a previous study, researchers used $30 \mathrm{~g} /$ day of Gum Arabic daily for 3 months to treat 100 diabetic patients and found that GA inhibited lipid peroxidation and glucose levels. Babiker et al. (2017) and Helal et al. used GA $7.5 \mathrm{~g} / \mathrm{kg} /$ day orally for 10 days and GA exerts a protective effect against stress-induced gastric mucosal lesions in rats. Zha et al. (2018) used 100 or $200 \mathrm{mg} / \mathrm{kg}$ curcumin was administered orally to the diabetic rats for 16 weeks, (Rashid \& Sil, 2015) used $100 \mathrm{mg} / \mathrm{kg}$ for 8 weeks, curcumin may have a therapeutic value in the treatment of diabetes-induced testicular injury due to its prevention of testicular apoptosis and attenuation of oxidative stress and suggested that curcumin exerts a protective effect on STZ-induced testicular impairment by increasing testosterone hormone secretion, ROS/O2- production, and apoptosis, similar to the findings in this study. AG ameliorated the associated rise in blood pressure In diabetic mice (Nasir et al., 2012).

The effect of GA on testicular oxidative stress and sperm quality were investigated by Fedail et al. (2016), 10 

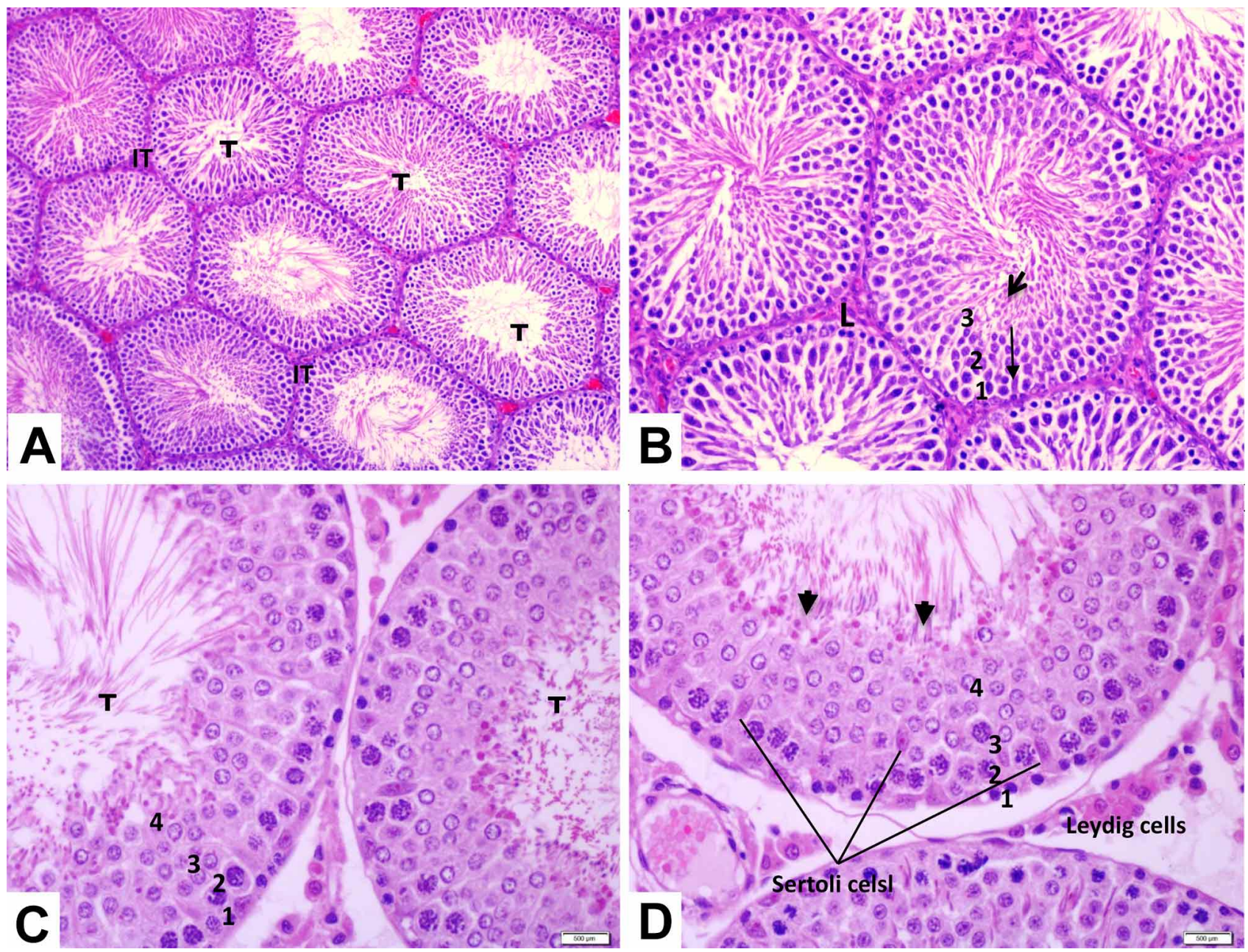

Fig. 1. A: Photomicrograph obtained from testis of a control rat showing normal seminiferous tubules (T) that appear hexagonal or circular with regular contour, and interstitial tissue (IT) contains a delicate loose CT and Leydig cells. The seminiferous tubules show a clear lumen and a normal arrangement of cellular types. $(\mathrm{H}$ and $\mathrm{E}, \times 100)$. B: High magnification Photomicrograph of control rat testis showing seminiferous tubules lined with series of spermatogenic cells; spermatogonia,(1) primary spermatocytes (2) and round (early) spermatids.(3) Sertoli cells (arrow) are seen with attached sperms (arrow head). Tubules are surrounded by basement membrane . The interstitial spaces in-between the tubules contain interstitial cell of Leydig $(\mathrm{L})$ having vesicular nucleus with prominent nucleolus. (H and E, $\times 400)$. C-D: Photomicrograph of testis of a control rat (G1) showing seminiferous tubules lined with series of spermatogenic cells; spermatogonia,(1) $1^{\text {st }}$ spermatocytes (2), $2^{\text {nd }}$ spermatocytes (3) and spermatids.(4). Sertoli cells are seen with attached sperms (arrow head). (H and $\mathrm{E}, \times 400)$.

$\% \mathrm{GA}$ in the form of drinking water for 10 weeks, may protect testis via enhancement of anti-oxidant capacity in male Sprague-Dawley rats, it may be useful to meliorate the diabetic fertility complications. Apoptosis is considered the main contributing factor of testicular injury in experimental animals with DM due to elevated oxidative stress, increased ROS production induces lipid peroxidation, DNA damage and mitochondrial lesions in germ cells, leading to dysfunction in testicular spermatogenesis and steroidogenesis. Therefore, ameliorating oxidative stress and apoptosis in diabetic rats represents a method to attenuate testicular damage (Dkhil et al.).
In the present study, we found that induction of diabetes in rats resulted in reduction of spermatogenic cells and is associated with degeneration in the spermatogenic cell series and congestion interstitial vessel. Diabetes has been reported to reduce the number of spermatogenic cells, and the diameter of the seminiferous tubules, apoptosis and atrophy in the seminiferous tubules, which are indicators for the failure of spermatogenesis as documented by Dkhil et al. Diabetes-induced atrophy of the sex organs and seminiferous tubules has been reported to be induced by oxidative stress and apoptosis (Navarro-Casado et al., 2010). 

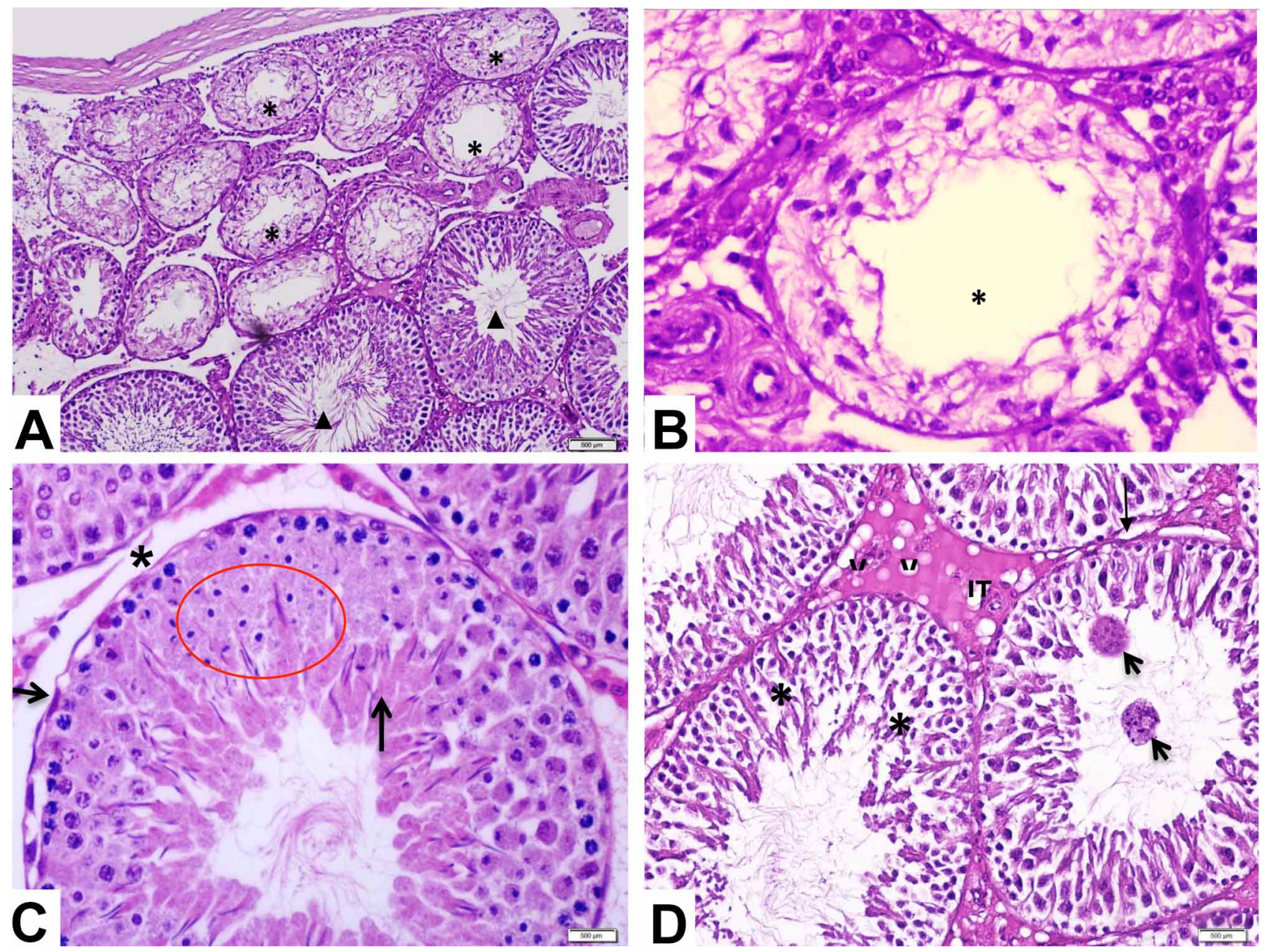

Fig. 2. A: Photomicrograph of testis diabetic-rat (G2) showing the heterogeneity of spermatogenesis= tubules have spermatogenesis $(\mathrm{s})$ and the adjacent tubules show absence of spermatogenesis $(*)$, severe degenerative change and atrophy of seminiferous tubules $(*)$. Absence of spermatogenesis in the atrophy of seminiferous tubules. ( $\mathrm{H}$ and $\mathrm{E}, \times 100)$. B: High magnification photomicrograph obtained from Testis treated-rat $(\mathrm{G} 2)$ showing severe degenerative change and atrophy of seminiferous tubules $(*)$. Absence of spermatogenesis in atrophied seminiferous tubules. ( $\mathrm{H}$ and $\mathrm{E}, \times 400)$. C: Photomicrograph of testis diabetic-rat $(\mathrm{G} 2)$ showing Hypospermatogenesis or oligozoospermia (Reduction in the sperms), pyknotic and necrotic spermatogenic cells (circle) with immature spermatids (arrow), irregular basement membrane (arrow head) and widening of the intertubular space $(*)$ with distorted and reduction in interstitial tissue (arrow heads) (H and E, $\times 400)$. D: High magnification photomicrograph of testis diabetic-rat $(\mathrm{G} 2)$ showing several spermatid giant cells in tubules with some degenerative changes like vacuoles (v), edema and widening of the interstitial tissue (IT), sloughing germinal epithelium and irregular basement membrane (arrows) and germinal cells atrophy $(*)$. (H and E, $\times 100)$.

Ozdemir et al. (2009) mentioned to the difference between the diabetic groups and control in degeneration of the seminiferous tubules, tubule abnormality, giant cell formation, interstitial changes, apoptosis incidence and necrosis in the seminiferous tubules that agreed with the present findings, this was considered to be due to the degeneration of the seminiferous tubules. El-Nagar revealed that Arabic gum exerted a significant hypoglycemic effect by release of insulin from pancreatic beta cells, that agreed with the present findings that treated diabetic rats with Arabic gum showed reduced histopathological alterations alloxan- induced in testes compared to diabetic group. In contrast, we demonstrated that GA prevent and minimize diabetesinduced spermatogenic cell loss in the diabetic rats. These observations indicate that the spermatogenic cell-protective effects of GA may reflect the antioxidant nature of GA in biological systems as well as its fundamental role in sperm maturation. The effect of AG on histological changes was associated with significant histological protective features. The features of seminiferous tubules and interstitial tissue in the AG-treated group alone or with insulin for 30 days after diabetes was significantly similar to the control group. 

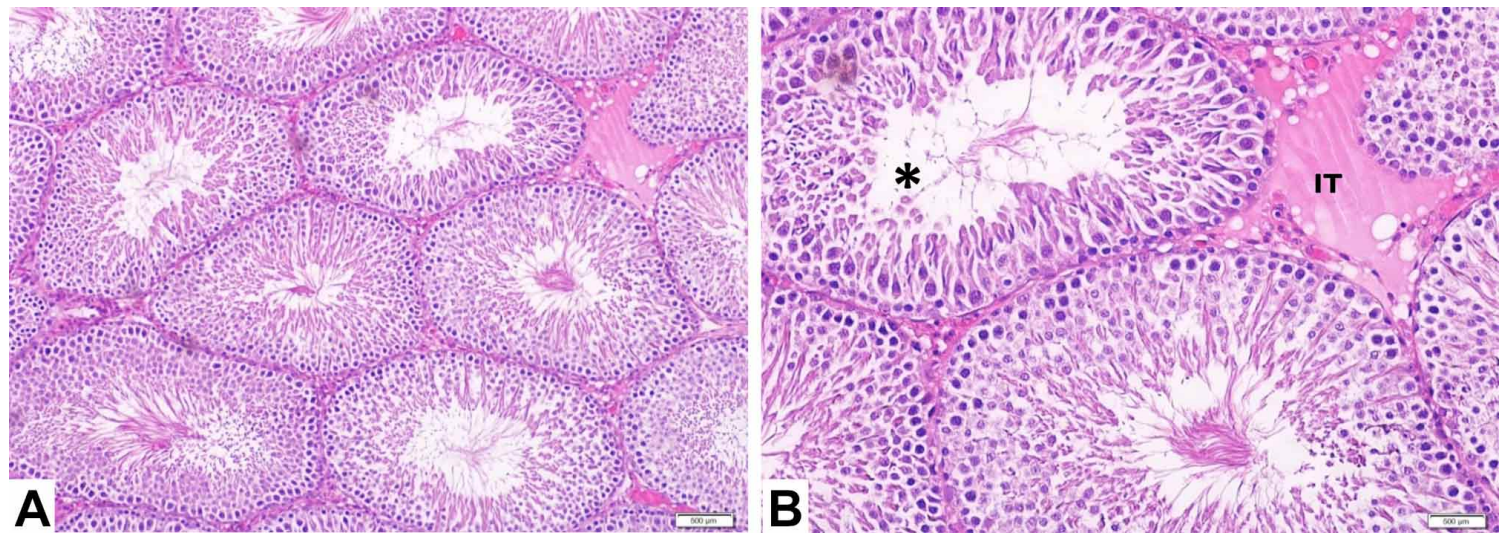

Fig. 3. A: Photomicrograph obtained from testis of a rat from G3(Diabetes + Arabic gum) showing improved testicular arrangement, seminiferous epithelium with spermatogonia, Sertoli cells, primary spermatocytes, spermatids and spermatozoa in the lumen. (H and E, $\times 100$ ). B: High magnification photomicrograph obtained from testis of a rat from G3 (Diabetes + Arabic gum) showing the restoration of spermatogenic cells in most seminiferous tubules, absence spermatozoa in some tubules $(*)$ and mild interstitial hemorrhage with edema and widening of the interstitial tissue (IT). (H and E, $\times 400$ ).
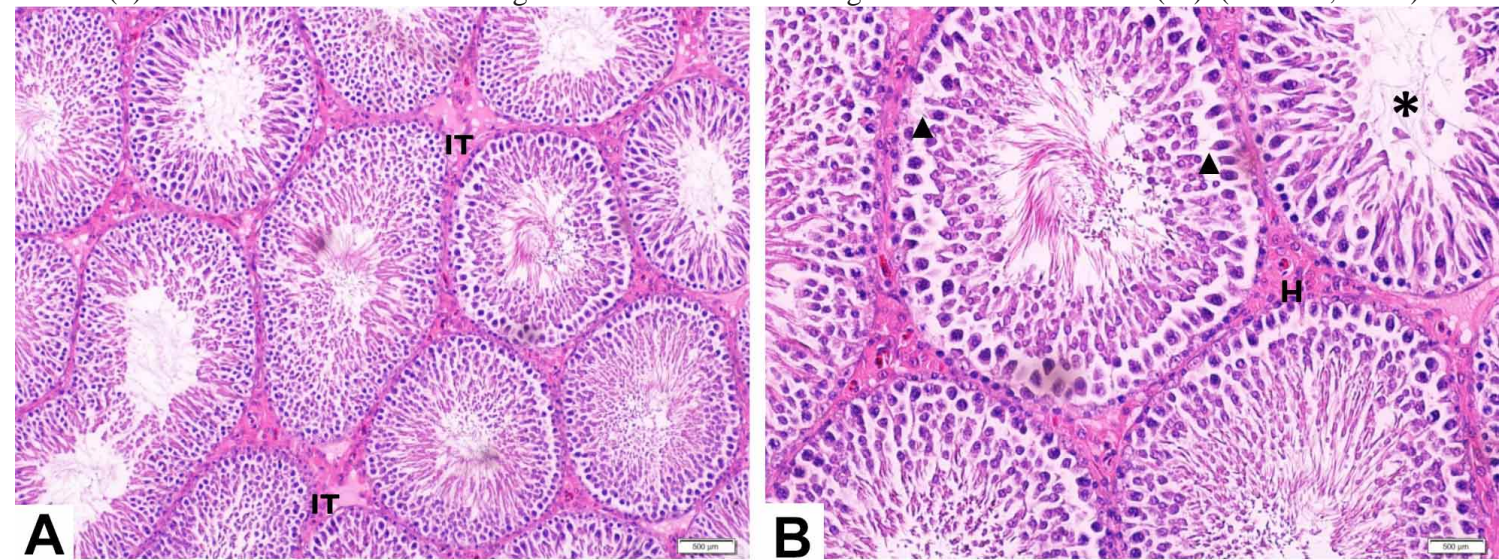

Fig. 4. A: Photomicrograph obtained from testis of a rat from G4 (Diabetes + Insulin) showing normal structure of seminiferous tubules with mild interstitial hemorrhage with edema and widening of the interstitial tissue (IT) (H\&E). (H and $\mathrm{E}, \times 100)$. $\mathrm{B}$ : High magnification photomicrograph obtained from testis of a rat from G4 (Diabetes + Insulin) showing the restoration of spermatogenic cells in most seminiferous tubules, absence or few spermatozoa in some tubules $(*)$, detached spermatogenic cells from basement membrane (arrow heads) and mild interstitial hemorrhage $(\mathrm{H})$, . (H and E, $\times 400)$.
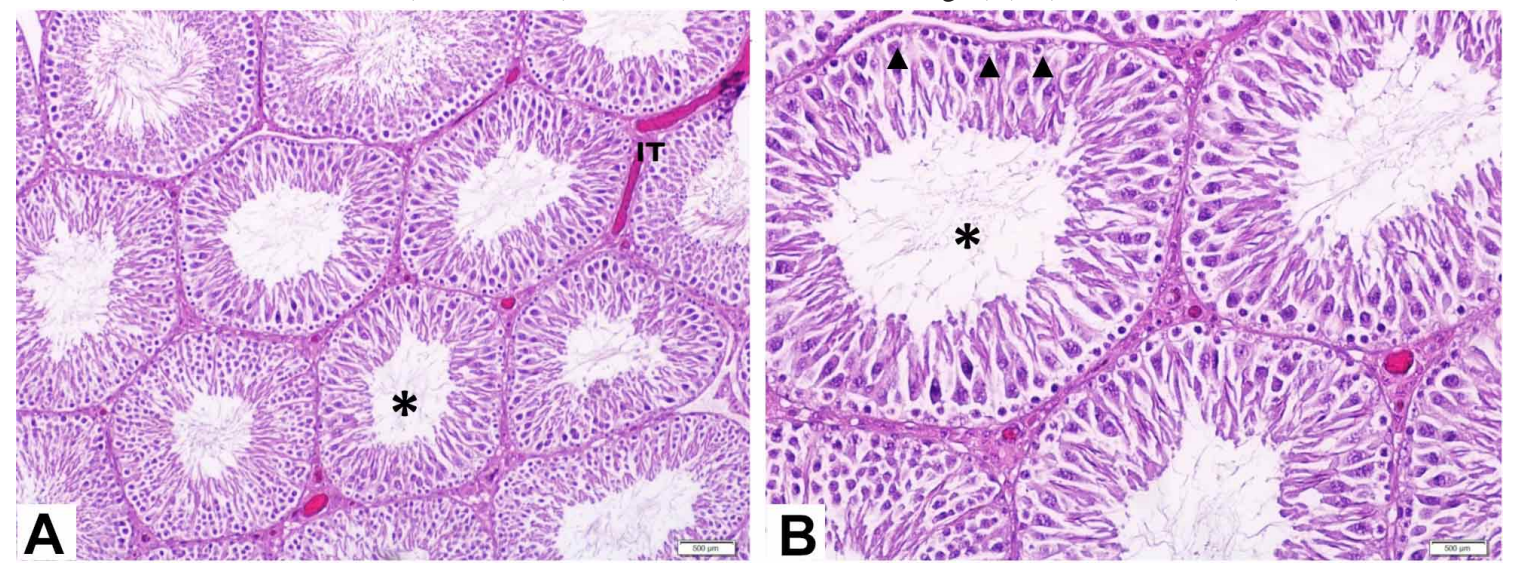

Fig. 5. A: Photomicrograph obtained from testis of a rat from G5 (Diabetes + Insulin + Arabic gum) showing normal structure of seminiferous tubules with few spermatozoa in some tubules $(*)$, dilated blood vessels in the interstitial tissue (IT). (H and E, $\times 100)$. B: High magnification photomicrograph obtained from testis of a rat from G5 (Diabetes + Insulin + Arabic gum) showing normal structure of seminiferous tubules, with few spermatozoa in some tubules (*) and irregular basement membrane (arrow heads). (H and $\mathrm{E}, \times 400)$. 


\section{CONCLUSION}

From this study, we concluded that oral administration of GA alone or with insulin, daily for 4 weeks successfully ameliorated the testicular histological alterations as evidenced by histopathological examination. Good improvements in testicular tissue had been observed. The possible mechanisms of this action might be ascribed to their anti-inflammatory, antioxidant, and histological protective effects.

\section{ACKNOWLEDGMENTS}

The authors extend their appreciation to the Deanship of Scientific Research at King Khalid University, Abha, KSA for funding this work through General Research Project under grant number (G.R.P/563/40).

AL-DOAISS, A. A. \& AL-SHEHRI, M. A. Efecto protector de la goma arábiga / insulina contra los cambios histológicos en los testículos de ratas diabéticas. Int. J. Morphol., 38(2):240-247, 2020.

RESUMEN: La diabetes mellitus es una enfermedad grave con una alta incidencia en nuestra comunidad. La goma arábiga (GA) es un polisacárido con propiedades antioxidantes importantes, y se ha utilizado para reducir la toxicidad experimental. Sin embargo, los efectos de GA sobre el tejido testicular en ratas diabéticas tipo I no se ha investigado lo suficiente. El estudio fue diseñado para pesquisar los cambios histológicos en los testículos de ratas Wistar macho e investigar el potencial protector de GA contra la toxicidad testicular inducida por la diabetes en ratas. Fueron asignadas cincuenta ratas Wistar macho adultas en cinco grupos ( $\mathrm{n}=10$ de cada una): el grupo 1 (ratas no diabéticas) sirvió como control, el grupo 2 sirvió como grupo diabético inyectado con Alloxan, grupo diabético del grupo 3 más insulina. El grupo 4 diabético recibió $15 \%$ de GA en agua potable, y el grupo diabético 5 más insulina y GA durante 4 semanas. Al comparar con el grupo control, los exámenes histopatológicos del tejido testicular del grupo de ratas diabéticas mostraron degeneración, necrosis y atrofia de los túbulos seminíferos con presencia de células gigantes, necrosis y hemorragia en el tejido renal. Por otra parte, el tratamiento con GA mejoró todos los cambios histológicos previos. En general, la administración oral de GA solamente, o con insulina diariamente durante 4 semanas mejoró los cambios histológicos testiculares. Estos datos demostraron que GA mejoró significativamente los efectos de la diabetes en testículos de rata. Este estudio sugiere que GA podría tener un efecto protector contra las funciones testiculares deterioradas, inducidas por el estrés oxidativo en ratas diabéticas. Los posibles mecanismos de esta acción podrían atribuirse a sus propiedades antioxidantes y antiinflamatorias.

PALABRAS CLAVE: Diabetes mellitus; Testículos; Goma arábiga; Histología; Rata.

\section{REFERENCES}

Al-Doaiss, A. A. \& Jarrar, Y. B. Investigation of in vivo protective effect of orally administered vitamin $\mathrm{E}$ and selenium against gentamicin-induced renal and hepatic toxicity. Trop. J. Pharm. Res., 18(7):1435-42, 2019.

Al-Doaiss, A. A.; Ali, D.; Ali, B. A. \& Jarrar, B. M. Renal Histological Alterations Induced by Acute Exposure of Titanium Dioxide Nanoparticles. Int. J. Morphol., 37(3):1049-57, 2019.

Ali, B. H.; Beegam, S.; Al-Lawati, I.; Waly, M. I.; Al Za'abi, M. \& Nemmar, A. Comparative efficacy of three brands of gum acacia on adenineinduced chronic renal failure in rats. Physiol. Res., 62(1):47-56, 2013.

Almalki, D. A.; Alghamdi, S. A. \& Al-Attar, A. M. Comparative study on the influence of some medicinal plants on diabetes induced by streptozotocin in male rats. BioMed Res. Int., 2019:3596287, 2019.

Babiker, R.; Elmusharaf, K.; Keogh, M. B.; Banaga, A. S. I. \& Saeed, A. M. Metabolic effects of Gum Arabic (Acacia Senegal) in patients with Type 2 Diabetes Mellitus (T2DM): Randomized, placebo controlled double blind trial. Funct. Foods Health Dis., 7(3):219-31, 2017.

Cheng, D.; Liang, B. \& Li, Y. Antihyperglycemic effect of Ginkgo biloba extract in streptozotocin-induced diabetes in rats. BioMed Res. Int., 2013:162724, 2013.

Dag, A.; Frrat, E. T.; Uysal, E.; Ketani, S. \& Ketani, M. A. Histological investigation of the impact of streptozotocin-induced experimental diabetes on the healthy gingivae of rats. Biotechnol. Biotechnol. Equip., 28(4):710-5, 2014

Dkhil, M. A.; Zrieq, R.; Al-Quraishy, S. \& Moneim, A. E. A. Selenium nanoparticles attenuate oxidative stress and testicular damage in streptozotocin-induced diabetic rats. Molecules, 21(11):1517, 2016.

El-Nagar, D. M. Pancrease-protective effects of arabic gum on diabetic type 2 streptozotocin-induced in albino mice. Res. J. Pharm. Biol. Chem. Sci., 8(1):1263-1270. 2017.

Elshama, S. S. The preventive role of Arabic gum in the treatment of toxicity. Toxicol. Res., 1(1):27-9, 2018.

Fedail, J. S.; Ahmed, A. A.; Musa, H. H.; Ismail, E.; Sifaldin, A. Z. \& Musa, T. H. Gum arabic improves semen quality and oxidative stress capacity in alloxan induced diabetes rats. Asian Pac. J. Reprod., 5(5):434-41, 2016.

Hammad, F. T.; Al Salam, S.; Nemmar, A.; Ali, M. \& Lubbad, L. The effect of arabic gum on renal function in reversible unilateral ureteric obstruction. Biomolecules, 9(1):25, 2019.

Helal, O.; Yousef, M. \& Elnaa, M. Possible protective effect of gum arabic on experimentally induced gastric ulcer in adult male albino rats: a histological and immunohistochemical study. Egypt. J. Histol., 34(3):546-53, 2011.

Meier, J. J. \& Bonadonna, R. C. Role of reduced b-cell mass versus impaired b-cell function in the pathogenesis of type 2 diabetes. Diabetes Care, 36(Suppl. 2):S113-9, 2013.

Nasir, O. Renal and extrarenal effects of gum arabic (Acacia Senegal )-What can be learned from animal experiments? Kidney Blood Press Res., 37(4-5):69-79, 2013.

Nasir, O.; Umbach, A. T.; Rexhepaj, R.; Ackermann, T. F.; Bhandaru, M.; Ebrahim, A.; Artunc, F.; Kempe, D. S.; Puchchakayala, G.; Siraskar, B.; et al. Effects of gum arabic (Acacia Senegal) on renal function in diabetic mice. Kidney Blood Press Res., 35(5):365-72, 2012.

Navarro-Casado, L.; Juncos-Tobarra, M. A.; Cháfer-Rudilla, M.; Íñiguez de Onzoño, L.; Blázquez-Cabrera, J. A. \& Miralles-García, J. M. Effect of experimental diabetes and STZ on male fertility capacity. Study in rats. J. Androl., 31: 584-92, 2010.

Nemmar, A.; Al-Salam, S.; Beegam, S.; Yuvaraju, P. \& Ali, B. H. Gum arabic ameliorates impaired coagulation and cardiotoxicity induced by water-pipe smoke exposure in mice. Front. Physiol., 10:53, 2019.

Ozdemir, O.; Akalin, P. P.; Baspinar, N. \& Hatipoglu, F. Pathological changes in the acute phase of streptozotocin-induced diabetic rats. Bull. Vet. Inst. Pulawy, 53(4):783-90, 2009. 
Pashapoor, A.; Mashhadyrafie, S. \& Mortazavi, P. Ameliorative effect of Myristica fragrans (Nutmeg) extract on oxidative status and histology of pancreas in Alloxan induced diabetic rats. Folia Morphol. (Warsz.), 2019. doi: 10.5603/FM.a2019.0052. In press.

Popoola, B.; Ashefor, O.; Akanni, O. \& Adaramoye, O. Biochemical, hormonal and histological changes in prostate of Wistar rats following long term streptozotocin-induced diabetes mellitus. Niger. J. Physiol. Sci., 32(1):75-84, 2017.

Rashid, K. \& Sil, P. C. Curcumin ameliorates testicular damage in diabetic rats by suppressing cellular stress-mediated mitochondria and endoplasmic reticulum-dependent apoptotic death. Biochim. Biophys. Acta, 1852(1):70-82, 2015.

Said, A. M.; Atwa, S. A. E. \& Khalifa, O. A. Ameliorating effect of gum arabic and lemongrass on chronic kidney disease induced experimentally in rats. Bull. Natl. Res. Cent., 43:47, 2019.

Zeid, I. M. A. \& FarajAllah, A. R. Gum Arabic and Kidney Failure: An Exceptional Panacea. In: Mariod, A. A. (Ed.). Gum Arabic, Structure, Properties, Application and Economics. Cambridge (Massachusetts), Academic Press, Elsevier, 2018.

Zha, W.; Bai, Y.; Xu, L.; Liu, Y.; Yang, Z.; Gao, H. \& Li, J. Curcumin attenuates testicular injury in rats with streptozotocin-induced diabetes. BioMed Res. Int., 2018:7468019, 2018.

\section{Corresponding author: Amin Abdullah Al-Doaiss Department of Biology \\ College of Science \\ King Khalid University \\ P.O.Box: 9004 \\ Abha \\ Postal Code 61413 \\ SAUDI ARABIA}

Email: aaldoaiss@kku.edu.sa

Received: 30-07-2019

Accepted: 23-09-2019 